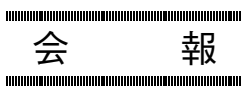

\title{
新規入会者のお知らせ
}

日本神経回路学会に入会された方は以下のとおり. 2015 年 7 月 松田孟留, 石㠃智紀, ZAINAL ZAEM ARIF, 荃山 冕行, 新垣 万, 佐藤 匡, 菊池 勇作, 岡藤 勇希 2015 年 8 月 井尻哲也, 日野 英冕, 浦久保 秀俊,

\section{$\diamond$ 訃}

日本神経回路学会名誉会員であられ, 日本神経回路 学会のロゴマークをデザインされた樋渡涓二先生が平 成 27 年 9 月 15 日永眠いたしました. 享年 93 歳でご ざいました。
柳下 祥, 為井 智也, 大林 千尋, 佐 藤 翔一郎, 我妻 伸彦, 中本 竣, 浦 瀬 康平, 佐野 崇, 西山 悠, 泉 慎 太郎, 佐藤 拓海, 小岩井 誠

2015 年 9 月 鈴木 聡志

\section{『学会などのご案内}

\section{主催学会}

1. The 23rd International Conference on Neural Information Processing (ICONIP2016 Kyoto)

期 日: 2016 年 10 月 16 日 (日) 21 日 (金)

会 場 : 京都大学 百周年時計台記念館

申込・問合せ先 : http://www.iconip2016.org/ 協賛学会

1. 第 16 回計測自動制御学会システムインテグ レーション部門講演会

主 催：計測自動制御学会 システムインテグレー

$$
\text { ション部門 }
$$

期 日： 2015 年 12 月 14 日(月) 16 日(水)

会 場 : 名古屋国際会議場

申込・問合せ先 :

http://www.si-sice.org/si2015/index.html

2. 第 8 回コンピューテーショナル・インテリジェ ンス研究会

主 催: 計測自動制御学会 システム・情報部門

期 日: 2015 年 12 月 18 日 (金) 19 日 (土)

会 場：県立広島大学広島キャンパス

申込・問合世先：

http://www.sice.or.jp/ci/8th_ci.html

県立広島大学経営情報学部

市村 匠：ichimura@pu-hiroshima.ac.jp

3. 進化計算シンポジゥム 2015

主 催: 進化計算学会
期 日： 2015 年 12 月 19 日 (土) 20 日 (日)

会 場：グリーンホテル三ヶ根

申込・問合せ先 :

http://www.jpnsec.org/symposium201503.html ecsymp2015@jpnsec.org

4. 計測自動制御学会関西支部・システム制御情報 学会 若手研究発表会 2015

主 催：計測自動制御学会関西支部，システム制 御情報学会

期 日: 2016 年 1 月 8 日 (金)

会 場：大阪大学吹田キャンパス 銀杏会館

申込・問合せ先：

http://www.osakac.ac.jp/sice_sympo2015/siceksympo15.htm

5. 第 28 回自律分散システム・シンポジゥム

主 催: 計測自動制御学会 システム・情報部門

期 日：2016年 1 月 21 日(木) 22 日(金)

会 場：広島大学東広島キャンパス 学士会館 申込・問合せ先 :

http://www.ohk.hiroshima-u.ac.jp/das2016/

6. 第 31 回国際心理学会議 (ICP2016)

主 催：日本心理学会

期 日：2016年 7 月 24 日(日) $~ 29$ 日(金)

会 場: パシフィコ横浜

申込・問合せ先：URL: http://www.icp2016.jp/ ICP2016 Office info@icp2016.jp 


\section{5 年度日本神経回路学会 総会 議事録}

日時: 2015 年 9 月 4 日 (金) 16:40 18:00

場所: 電気通信大学

・総会の成立について

委任状 $130+$ 出席者 71 名なので総会は成立した

- 年次活動報告（酒井会長）

JNNS の年次活動報告として以下の活動に関して酒 井会長からの説明が行われた.

- 全国大会

- 各種スクール支援 $($ 春・夏・秋)

- 時限研究会などの支援

・「脳と心のメカニズム」参加助成

- 学会誌, 英文誌, 電子化

- 会計報告 (佐藤俊治理事, 鹿毛会計監査)

> 収支の改善が見られるが Neural Networks の 払戻金における為替の影響が大きいとの報告が あった。

> 会計監査 (鹿毛理事) により, 今年度の会計に ついて適正な支出であることを確認されたとの 報告がされた。

> 次に佐藤理事より 2015 年度の予算の説明がな され，収入においては論文募集が停止になった ために変更が生じていること, 支出においては APNNS 設立準備金として活動費, 設立補助費 が計上されたことが説明された。

- 事業報告

> 和文誌報告 (鮫島理事)

編集委員長の交代が理事会で承認されたことと 編集委員は理事から選出すること報告された.

$>$ Neural Networks 誌 (黒柳理事)

2015 年 8 月現在で 172 件の投稿（中国 88 件, インド 43 件, 日本 12 件) があり, IF が 2.7 に
改善したことが報告された.

> 主催セミナー (黒柳理事)

Deep learning セミナーに 112 名の参加者があ り盛況に終わったこと, 時限研究会として共催 1 件, 協催 3 件があり, 2016 年度も引き続き募 集する旨告知された.

> 若手支援 (鮫島理事) スプリングスクールの学生宿泊費・食事代として 27 万円の補助がなされたこと, ASCONE2015 について 120 万円の補助を予定していること, 冬の WS について 40 万円の補助を予定してい ることが報告された．

>国際関係 (酒井会長)

APNNS が今年 11 月に発足を予定しており，現 在会員数は， 227 名となっていることが報告さ れた。

> 脳科連について (酒井会長)

マスタープラン 2017 を策定し, 関係分野への 予算獲得を目指す活動を実施することが説明さ れた。

> ICONIP2016 (西川理事) 2016 年 10 月 16 日 10 月 21 日に京都大学で 開催される。

- 選奨報告 (選考委員長西川理事)

西川理事より, 規程に従い, 論文賞, 優秀研究賞, 大 会奨励賞がそれぞれ選奨されたことが報告された。

- 選奨表彰 (酒井会長, 西川理事)

本会に受賞された方のうち 15 名のご列席をいただ き, 酒井会長より賞状をお渡しするとともに, 一言 ずつ受賞のコメントをいただいた。

\section{日本神経回路学会 2015 年度第 2 回理事会 議事録}

日時： 2015 年 9 月 3 日（木） 12:20 14:20

場所：電気通信大学・東 4 号館 802 号室

出席：

酒井宏会長，小澤誠一副会長

【理事】赤穗昭太郎理事, 大森隆司理事, 鹿毛裕史理事, 北野勝則理事, 黒柳奨理事, 阪口豊理事, 佐藤俊治理 事, 佐藤直行理事, 鮫島和行理事, 柴田克成理事, 庄 野逸理事, 立野勝巳理事, 田向権理事, 西川郁子理事,
宮脇陽一理事

【特任理事】池田和司特任理事, 五味裕章特任理事, 銅 谷賢治特任理事, 廣瀬明特任理事

【欠席】(委任状あり)

小池康晴理事, 佐藤茂雄理事, 中原裕之理事, 庭野道 夫理事, 林勲理事, 川人光男特任理事, 山口陽子特任 理事

(五十音順) 
0. 各理事の自己紹介の後, 前回の議事録について,す でにメール審議で承認済みであることが確認された。

\section{JNNS2015 報告}

阪口理事より開催中の JNNS2015について報告がさ れた. 発表件数は 95 件で, 理事会開催時点では約 240 名（最終は 258 名）の参加があったことが報告された.

2. 選奨報告（メール審議済み）

西川理事より配布資料に基づき選奨結果が報告され た。選奨委員会の結果, 論文賞に 2 編, 最優秀研究賞 1 編，優秀研究賞 3 編が選出された。論文賞の 2 編は 同点一位であった。 大会奨励賞は応募数 35 編（うち 2 編は応募辞退）のなかから 5 編程度を選ぶ予定である ことが報告された。また会長より先の理事会で提起さ れ, 議論が継続している論文賞の方針に関する審議は, 現在検討中であり，次回理事会で提案を予定している との報告がされた。

3. 2015 年度上半期会計報告

佐藤俊治理事より配布資料に基づき 2015 年度上半 期会計報告がされた。 円安により Neural Networks 誌 の払戻金が多く，収入が改善した。ただし，円安の恩 恵であるため, 収支の改善は引き続き課題であること も指摘された。

4. 事業報告

4-1. 学会誌出版報告

【審議事項】出版報告に先立ち, 編集委員長を池田特 任理事から鮫島理事へ交代することが承認された。ま た，神経回路学会和文誌が論文投稿を受け付けなくな り，広報誌的存在になったことから，今後編集委員は 理事から選ぶことも承認された。今年度の編集体制は 現状のままで，3月の理事会において次期編集委員に ついて諮り，その後新たな体制での編集がなされる.

【報告】鮫島理事より，配布資料に基づき，日本神経回 路学会和文誌の出版費用が説明された.

\section{4-2. Neural Networks 誌出版報告}

銅谷特任理事より，Neural Networks 誌が年 12 回 順調に発行されていることが報告された。 IF が 2.708 に改善した。査読日数は平均 35 日であった。昨年 231 件の投稿があり，今年はこれまでで 172 件 (うち 101 件 が不採択）の投稿がなされた。国別に見ると，中国 88 件，インド 43 件，日本 12 件の順である。また， 2014 年 IF のもととなる 2012～13 年に出版された論文の引 用数ベスト 20 のなかに日本からの論文が含まれてい なかった．Special Issue の発刊を予定しており，Big Data, Neurobiologically Inspired Robotics の特集が 予定されている. 日本からの積極的な論文投稿を依頼 された。

\section{4-3. 平成 27 年度時限研究会実施報告}

柴田理事より配布資料に基づき，時限研究会「眼球 運動を制御する小脳中枢機構の理解へのデー夕駆動型 アプローチ」について説明がされた，参加者数は，海 外からの 3 名を含む, 30 名であった。本学会からの補 助金については，当初海外からの 2 名の講師の招聘費 用に充てる予定であったが，渡航費用が高額になった ため，海外からの 1 名の招聘費用と，国内からの 1 名 の講師謝金に充てたことなどが報告された。

4-4. Deep learning セミナー報告

柴田理事より配付資料に基づき, 神経回路学会主催 セミナー「Deep learning をつかってみよう!」の報告 がされた。参加者は講師 2 名を除き，112 名であった。 うち, 神経回路学会会委員は 25 名で, 学生が 43 名, 民間企業からの参加も 25 名であった。講師の先生に は事前の準備から損いし，想定を上回る負担となっ たため, 会長と会計担当理事と相談の上，謝金を当初 の 2 万円から 3 万円としたことなどが報告された.

4-5. 共催研究会報告

五味理事より配布資料に基づき，シンポジウム「未 知の克服と環境認知のための身体性情報処理」につい て報告された。 3 名の招待講演者による講演が行われ た. 他との共催であったため, 神経回路学会の負担は 講師謝金としての 3 万円のみであった。

4-6. 協催研究会報告

宮脇理事より配布資料に基づき，電通大主催のシン ポジウム「Object Vision in Human, Monkey, and Machine」(2015 年 11 月 5～6 日開催) に協催するこ とが報告された。参加者は 90 名ほどを見达んでいる. 開催資金の負担はない。

4-7. 協催研究会報告

酒井会長より, 配布資料に基づき, 理化学研究所・脳科 学総合研究センター主催の「3rd Mini Symposium on Cognition, Decision-making and Social function」 (2015 年 4 月 20 日開催）と「2nd Mini Symposium on Computations, Brains and Machine」(2015 年 7 月 14 日開催）に協催したことが報告された。いずれ も参加者は 50 名ほどであった。

5. 若手支援報告

5-1. 各種スクール支援報告

赤穂理事より，配布資料に基づき，「システム神経 科学スプリングスクール SNSS2015」（2015 年 3 月 6 日〜8 日開催) の開催報告と「オータムスクール ASCONE2015」(2015 年 10 月 31 日〜 11 月 3 日開催)の予 定について報告された。 スプリングスクール SNSS2015 の開催記事は和文誌 22 巻 2 号に掲載済みである. 


\section{5-2. 夏冬 WS についての報告}

北野理事より, 夏のワークショップが開催されなかっ たが，冬は開催される予定であることが報告された。 報告の中で，年 1 回開催の場合の予算について問題提 起がされ，継続して検討することとなった。

5-3. 国際会議英文添削支援報告

立野理事より，配布資料に基づき，ICONIP2015の 投稿に対して添削支援を募ったが，応募者がいなかっ たことが報告された。また，年度内に ICONIP2016で の募集を検討していることが報告された．

6. 脳科学関連学会連合報告

酒井会長より, 配布資料に基づき, 脳科学関連学会 連合活動について，マスタープラン 2017 を策定する 予定であることが報告された。また，「脳とこころ」・ 「神経科学」「脳と意識」分科会合同シンポジウム「求 められる「脳とこころの科学」〜教育・医療・モノづ くり〜」への積極的な参加が依頼された.

7. 国際関係報告

\section{7-1. ANNS 報告}

小澤副会長より配布資料に基づき，APNNS の設立 準備状況, APNNS 会員加入状況について報告された. APNNS 会員は 2015 年 8 月 27 日時点で 224 名（う ち JNNS 会員は 139 名). JNNS 会員以外は 85 名で, 国別に見ると，中国 52 名，オーストラリア 6 名，マ レーシア 6 名, 香港 5 名, UAE3 名, 夕イ 2 名, ほか に 11 力国からそれぞれ 1 名である.日本以外からの 参加が少なく, また JNNS 会員の加入率も低いので, AAPNNS 理事，およびJNNS 理事に呼びかけを行う よう依頼された。現在, President, Elected Governor の選挙準備や APNNS 事務局の設置などが進められて いる. APNNS 支援業務費用の見積書が報告された（支 援業務と支援額については 2015 年第 1 回理事会にて 承認済みである).

\section{7-2. ICONIP2016 準備報告}

廣瀬特任理事より ICONIP2016（2016 年 10 月 16 日〜21 日開催)の準備状況が報告された。ICONI‘2016
は新たな主体としての APNNS と新体制での ICONIP の特色を出すことによって，これまでICONIP から分 岐したコミュニティを呼び戻し, 新たなアイデアの種を 生み出す土壤となるような大会となることを目指して いることが説明された。開催までのスケジュールが示 され, 特別講演者が内定済みであることや Proceedings 出版が Springer 社に決定したことなどが報告された. また，運営会社は株式会社 JTB 西日本に決定したこ とが報告された。選奨については, ICONIP の賞のみ 設け, 日本神経回路学会としての賞は設けないことが 確認された。ただし，日本神経回路学会の理事会と総 会は, ICONIP 開催中に開催する。

\section{8. 法人化検討【審議事項】}

酒井会長による趣旨説明として，学会としての銀行 口座をもてないこと, 税金への懸念, APNNS との関 係において国際的な信用性などの学会の問題点が示さ れ, 法人化についての議論が提起された. 法人化の検 討内容とその結果は, 田向理事より配布資料に基づき, 説明がされた．司法書士の見解などを示し，学会とし ては「NPO 法人」ょり「一般社団法人 (非営利型)」 が妥当である旨, 提案された。法人化の手続きは煩雑 ではあるが，代行業などもあり問題はない。問題は法 人化後の維持管理であることが指摘された。また，法 律に則った運営を行う必要があるので，これまで以上 に関係者の負担が増すことなどが懸念として示された. 審議の結果, 2016 年 3 月の理事会で法人化を進める方 針で議論することとなった.

9. 総会打合せ

黒柳理事より総会で示すスライドの確認が行われた。 10. そのほか

2017 年全国大会開催候補地の検討【審議事項】

酒井会長より，2017 年日本神経回路学会全国大会の 開催地を決定するため, 1997 年大会からの開催場所が 示された. 2017 年の開催地は九州工業大学の方向で調 整することになった。 


\section{日本神経回路学会 2014 年度収支計算書}

(2014 年 1 月 1 日から 2014 年 12 月 31 日まで)

（単位：円）

収入の 部

\begin{tabular}{|c|c|c|c|}
\hline 項目 & 予算 & 決算 & 備考 \\
\hline 会費収入 & $6,234,000$ & $6,322,000$ & 過年度会費の回収分を含む \\
\hline 入会金 & 68,000 & 94,000 & $\begin{array}{l}2014 \text { 年度 } 47 \text { 名 } \times ¥ 2,000 （ \text { 正会員 } 16 \text { 名, 学生会 } \\
\text { 員 } 31 \text { 名） }\end{array}$ \\
\hline 一般会員会費 & $5,629,000$ & $5,590,000$ & $\begin{array}{l}2014 \text { 年度分 } 413 \text { 名 } ¥ 5,369,000 \text { 過年度分 } 17 \text { 名 } \\
¥ 221,000\end{array}$ \\
\hline 学生会員会費 & 207,000 & 252,000 & 2014 年度分 80 名 $¥ 240,000$ 過年度分 4 名 $¥ 12,000$ \\
\hline 賛助会員会費 & 250,000 & 250,000 & 2014 年度分 5 口（3 社） $\times ¥ 50,000$ \\
\hline 英文誌購読費 & 80,000 & 136,000 & 2014 年度分 13 名 $¥ 104,000$ 過年度分 4 名 $¥ 32,000$ \\
\hline 出版関係収入 & $6,079,000$ & $9,143,198$ & \\
\hline 和文誌販売 & 58,000 & 68,600 & $\begin{array}{l}\text { Vol.20-3 (1 冊), Vol.20-4 (1 冊), Vol.21-1〜4 (10 } \\
\text { セット) }\end{array}$ \\
\hline 別刷販売 & 0 & 244,000 & $\begin{array}{l}\text { Vol.21-1 ( } 1 \text { 件), Vol.21-2 (2 件), Vol.21-3 ( } 2 \text { 件), } \\
\text { Vol.21-4 ( } 1 \text { 件) }\end{array}$ \\
\hline 大会論文集販売 & 0 & 4,164 & 第 24 回全国大会論文集 2 冊 \\
\hline Neural Networks 誌返戻金 & $6,021,000$ & $8,826,434$ & Neural Networks 誌編集費 \\
\hline 補助金払戻金 & 0 & 667,835 & \\
\hline ASCONE 残金 & 0 & 1,707 & ASCONE2013 残金 \\
\hline 全国大会残金 & 0 & 593,955 & JNNS2014（北海道）補助金払戻金 \\
\hline 時限研究会残金 & 0 & 72,173 & 2007 年度分残金および利子 \\
\hline 雑収入 & 100,000 & 18,631 & 銀行預金利息, 文献許諾使用料他 \\
\hline 小 & $12,413,000$ & $16,151,664$ & \\
\hline 前年度繰越金 & $29,645,815$ & $29,645,815$ & \\
\hline 合計 & $42,058,815$ & $45,797,479$ & \\
\hline
\end{tabular}


支出の 部

\begin{tabular}{|c|c|c|c|}
\hline 項目 & 予算 & 決算 & 備考 \\
\hline FLSI 事務費 & 200,000 & 153,535 & 封筒代, 宛名シール代他 \\
\hline 業務委託費 & $2,700,000$ & $2,621,818$ & \\
\hline 送料 & 408,000 & 352,133 & 和文誌発送費, 会費請求書送料他 \\
\hline 集会費 & $1,350,000$ & 952,314 & \\
\hline 会議費 & 300,000 & 110,040 & 理事会会議費, 理事会交通費他 \\
\hline 大会出資金（全国大会） & 500,000 & 500,000 & JNNS2014（北海道） \\
\hline 共催研究会助成金 & 100,000 & 22,274 & $\mathrm{NC}$ 研究会招待講演謝金 \\
\hline 若手助成金 & 400,000 & 320,000 & 第 14 回冬のワークショップ参加助成金 \\
\hline 英文原稿校閲費用 & 50,000 & 0 & \\
\hline 出版費 & $8,096,000$ & $8,850,786$ & \\
\hline 和文誌編集 ·印刷費 & $3,000,000$ & $3,236,772$ & 和文誌印刷代, 和文誌原稿料 \\
\hline 和文誌電子化費 & 160,000 & 168,480 & JSTAGE デー夕作成費用 \\
\hline Neural Networks 誌購読費 & $3,976,000$ & $4,703,934$ & \\
\hline NN 誌編集事務局人件費 & 960,000 & 741,600 & 編集事務局人材派遣費 \\
\hline 研究会運営補助金 & $1,670,000$ & $1,745,105$ & \\
\hline チュートリアル & $1,200,000$ & $1,200,000$ & 2014 年度 ASCONE 補助金 \\
\hline スプリングスクール & 300,000 & 270,000 & 2014 年度補助金 \\
\hline 時限研究会 & 170,000 & 137,689 & 2014 年度補助金 \\
\hline Deep Learning & 0 & 137,416 & 2014 年度補助金 \\
\hline 選奨費 & 250,000 & 210,000 & 2014 年度選奨賞金 \\
\hline ANNS 学会化準備費 & 440,000 & 0 & \\
\hline 雑費 & 100,000 & 112,580 & 振込手数料, 自動振替手数料, $\mathrm{Bz}$ 手数料他 \\
\hline 小 計 & $15,214,000$ & $14,998,271$ & \\
\hline 当期収支差額 & $-2,801,000$ & $1,153,393$ & \\
\hline 次期への繰越金 & $26,844,815$ & $30,799,208$ & \\
\hline
\end{tabular}

本決算報告書は, 監査の結果適正と認められ, 平成 27 年 9 月 3 日開催の理事会で承認されました.

財務・会計理事 佐藤 俊治 


\section{日本神経回路学会 2014 年度貸借対照表}

(2014 年 12 月 31 日現在)

(単位：円)

\begin{tabular}{|c|c|c|c|}
\hline \multicolumn{2}{|l|}{ 資産 } & \multicolumn{2}{|l|}{ 負債 ·資本 } \\
\hline \multicolumn{2}{|l|}{ 資産の部 } & \multicolumn{2}{|l|}{ 負債の部 } \\
\hline \multirow{10}{*}{$\begin{array}{l}\text { 1. 流動資産 } \\
\text { (1) 現金・預金 } \\
\text { 事務局現金 } \\
\text { 西日本シティ銀行・普通預金 }(\text { 事務局口座) } \\
\text { ジャパンネット銀行·普通預金 }(\text { 事務局口座 }) \\
\text { 三菱東京 UFJ 銀行・普通預金 } \\
\text { 西日本シテイ銀行・普通預金 } \\
\text { ゆうちょ銀行・普通預金 } \\
\text { ゆうちょ銀行・振替口座 } \\
\text { 三菱東京 UFJ 銀行・定期預金 } \\
\text { 西日本シテイ 銀行・定期預金 }\end{array}$} & \multirow{3}{*}{$\begin{array}{r}38,375 \\
148,655\end{array}$} & $\begin{array}{l}\text { 1. 流動負債 } \\
\text { (1) 預り金 }\end{array}$ & 22,737 \\
\hline & & \multirow[b]{3}{*}{ (2) 前受会費 } & 22,737 \\
\hline & & & \\
\hline & $2,425,765$ & & 176,000 \\
\hline & $4,645,456$ & \multirow[b]{3}{*}{ (3) 前受金 } & 176,000 \\
\hline & 19,382 & & \\
\hline & 104,560 & & 7,000 \\
\hline & $6,901,680$ & \multirow[b]{3}{*}{ (4) 未払金 } & 7,000 \\
\hline & $10,000,000$ & & \\
\hline & $9,000,000$ & & $2,365,678$ \\
\hline \multirow{3}{*}{ (2) 未収金 } & $33,283,873$ & \multirow[t]{2}{*}{ 計 } & $2,365,678$ \\
\hline & 86,750 & & \\
\hline & 86,750 & 流動負債の部 合計 & $2,571,415$ \\
\hline \multirow[t]{4}{*}{ 流動資産の部 合計 } & $33,370,623$ & \multicolumn{2}{|l|}{ 資本の部 } \\
\hline & & 1. 前期繰越金 & $29,645,815$ \\
\hline & & 2. 当期収支差額 & $1,153,393$ \\
\hline & & 資本の部 合計 & $30,799,208$ \\
\hline 資産の部 合計 & $33,370,623$ & 負債・資本の部 合計 & $33,370,623$ \\
\hline
\end{tabular}

本決算報告書は, 監査の結果適正と認められ, 平成 27 年 9 月 3 日開催の理事会で承認されました.

財務・会計理事 佐藤 俊治 


\section{日本神経回路学会 2015 年度予算}

$(2015$ 年 1 月 1 日から 2015 年 12 月 31 日まで $)$

（単位：円）

収入の 部

\begin{tabular}{|c|c|c|c|}
\hline 項 目 & 2014 年度予算 & 2015 年度予算 & 備 \\
\hline 会費収入 & $6,234,000$ & $5,716,000$ & \\
\hline 入会金 & 68,000 & 68,000 & 34 名 $\times ¥ 2,000$ \\
\hline 正会員会費 & $5,629,000$ & $5,148,000$ & 396 名 $\times ¥ 13,000$ \\
\hline 学生会員会費 & 207,000 & 246,000 & 82 名 $\times ¥ 3,000$ \\
\hline 賛助会員会費 & 250,000 & 150,000 & 3 口 $(2$ 社 $) \times ¥ 50,000$ \\
\hline 英文誌購読費 & 80,000 & 104,000 & 13 名 $\times ¥ 8,000$ \\
\hline 出版関係収入 & $6,079,000$ & $7,340,000$ & \\
\hline 和文誌販売 & 58,000 & 59,000 & \\
\hline 別刷販売 & 0 & 122,000 & $\begin{array}{l}2013 \text { 年 } 12 \text { 月号より論文募集が停止になっ } \\
\text { たので, } 2014 \text { 年度実績の } 50 \% \text { 計上 }\end{array}$ \\
\hline Neural Networks 誌返戻金 & $6,021,000$ & $7,159,000$ & $\begin{array}{l}\text { Neural Networks 誌編集費 }(2014 \text { 年度実績は } \\
¥ 8,826,434)\end{array}$ \\
\hline 補助金払戻金 & 0 & 0 & \\
\hline 雑収入 & 100,000 & 100,000 & 銀行預金利息他 \\
\hline 計 & $12,413,000$ & $13,156,000$ & \\
\hline 前年度繰越金 & $29,645,815$ & $30,799,208$ & \\
\hline 合計 & $42,058,815$ & $43,955,208$ & \\
\hline
\end{tabular}


支出の 部

\begin{tabular}{|c|c|c|c|}
\hline 項 & 2014 年度予算 & 2015 年度予算 & 備 \\
\hline FLSI 事務費 & 200,000 & 200,000 & 封筒代, 宛名シール代他 \\
\hline 業務委託費 & $2,700,000$ & $2,700,000$ & 事務局業務委託費 \\
\hline 送料 & 408,000 & 385,000 & 和文誌発送費, 会費請求書送料他 \\
\hline 集会費 & $1,350,000$ & $1,955,000$ & \\
\hline 会議費 & 300,000 & 150,000 & $\begin{array}{l}\text { 理事会会議費, 理事会交通費他. } 2014 \text { 年度決算 } \\
\text { に応じて変更 }\end{array}$ \\
\hline 大会出資金（全国大会） & 500,000 & 500,000 & $\begin{array}{l}\text { JNNS2015 (東京) JNNS2016 全国大会は開催な } \\
\text { しを仮定 }\end{array}$ \\
\hline 大会出資金 (ICONIP2016 & 0 & 750,000 & ICONIP2007 (北九州) と同額 \\
\hline 京都) & & & \\
\hline 共催研究会助成金 & 100,000 & 100,000 & NC 研究会招待講演謝金他 \\
\hline 若手助成金 & 400,000 & 405,000 & 冬夏ワークショップ参加助成 \\
\hline 英文原稿校閲費用 & 50,000 & 50,000 & \\
\hline 出版費 & $8,096,000$ & $8,601,000$ & \\
\hline 和文誌編集 ·印刷費 & $3,000,000$ & $3,000,000$ & 和文誌印刷代, 和文誌原稿料 \\
\hline 和文誌電子化費 & 160,000 & 170,000 & J-STAGE デー夕作成費用 \\
\hline Neural Networks 誌購読費 & $3,976,000$ & $4,511,000$ & \\
\hline NN 誌編集事務局人件費 & 960,000 & 920,000 & 2014 年度決算額（ $¥ 741,600 ）$ に応じて変更 \\
\hline 研究会運営補助金 & $1,670,000$ & $1,845,000$ & \\
\hline チュートリアル & $1,200,000$ & $1,200,000$ & ASCONE2015 補助金 \\
\hline スプリングスクール & 300,000 & 300,000 & 2015 年度補助金 \\
\hline 時限研究会 & 170,000 & 0 & 2015 年度廃止 \\
\hline 戦略的企画 & & 345,000 & 2015 年度新設 \\
\hline 選奨費 & 250,000 & 250,000 & \\
\hline ANNS 学会化準備費 & 440,000 & 650,000 & 2014 年度より 新設 \\
\hline 国際活動費 & & 450,000 & JNNS 会員の ANNS 年会費助成. \\
\hline 設立補助費 & & 200,000 & 暫定事務局の初動経費不足分の立替. \\
\hline 雑費 & 100,000 & 100,000 & 振込手数料, 自動振替手数料, $\mathrm{Bz}$ 手数料他 \\
\hline 小 計 & $15,214,000$ & $16,686,000$ & \\
\hline 当期収支差益 & $-2,801,000$ & $-3,530,000$ & \\
\hline 次期への繰越金 & $26,844,815$ & $27,269,208$ & \\
\hline
\end{tabular}

本予算案は, 平成 27 年 9 月 3 日開催の理事会で承認されました.

財務 - 会計理事 佐藤 俊治 


\section{学会誌のJ-STAGE での公開}

学会誌のウェブ公開は, 利便性とアーカイブ化を求める社会の流れで, 学会誌に掲載の研究論文・解説・連載 を, J-STAGE（独立行政法人科学技術振興機構の科学技術情報発信・流通総合システム）にて公開しております.

記

\section{公開済み学会誌＼cjkstart創刊号より全巻全記事}

研 究 論 文 印刷版発行後約 2 ケ月後に J-STAGE 掲載. 会員／非会員の区別なく全文の閲覧可能.

解説・連載 印刷版発行後約 2 ケ月後にJ-STAGE 掲載. 電子版掲載後 1 年未満は, 会員のみが認証*に より全文の閲覧可能で, 非会員は題目と概要のみ閲覧可能. 発行から 1 年経過後は会員／非 会員の区別なく全文の閲覧が可能.

*会員閲覧用の ID とパスワードは，年末の会費請求時に同封した書面を参照.

*パスワードが不明の場合は，事務局にお問い合わせください.

参 考 (J-STAGE の URL) http://www.jstage.jst.go.jp/browse/jnns/-char/ja/

\section{イベントカレンダー}

2015 年 12 月 14 日 (月) 16 日 (水) 第 16 回計測自動制御学会システムインテグレーショ 名古屋国際会議場 ン部門講演会

2015 年 12 月 18 日 (金) 19 日 (土） 第 8 回コンピューテーショナル・インテリジェンス研 県立広島大学広島 究会

キャンパス

2015 年 12 月 19 日 (土) 20 日 (日) 進化計算シンポジウム 2015 グリーンホテル三 ヶ根

2016 年 1 月 8 日 (金) 計測自動制御学会関西支部・システム制御情報学会 大阪大学吹田キャ

\begin{tabular}{lll} 
& 若手研究発表会 2015 & ンパス銀杏会館 \\
\hline 2016 年 1 月 21 日 (木) 22 日 (金) & 第 28 回自律分散システム・シンポジウム & 広島大学東広島キ
\end{tabular}

\begin{tabular}{lll} 
& & ヤンパス \\
\hline 2016 年 7 月 24 日(日) 29 日(金) 第 31 回国際心理学会議 (ICP2016) パシフィコ横浜
\end{tabular}

2016 年 10 月 16 日 (日) 21 日 (金) The 23rd International Conference on Neural In- 京都大学百周年時 formation Processing (ICONIP2016 Kyoto)＼cjkstart計台記念館 